\title{
O ENVOLVIMENTO DA GESTANTE COM O
}

\section{PARTOGRAMA}

\section{INTRODUÇÃO}

O Partograma é a representação gráfica do trabalho de parto que permite acompanhar a sua evolução, evitando intervenções desnecessárias. As informações sobre a evolução do parto devem estar contidas no partograma, como dilatação cervical, os batimentos cardiofetais, dinâmica uterina e a administração de fluídos, verificando o tipo da evolução do parto eutócico ou distócico. O enfermeiro obstera segundo o COFEN 047/2015 possui responsabilidade de oferecer assistência tanto as gestantes, quanto às parturientes e puérperas, diante disso a resolução normativa - ANS $n^{\circ} 368 /$ 2015, é de direito das gestantes as informações dos índices de partos normais e cesáreos, o uso do cartão de gestantes e o partograma no ambiente hospitalar devem ser explicados de maneira clara e objetivas antes do parto e após o nascimento. Dentro das atribuições do enfermeiro obstetra, este é preparado para atuar durante a assistência a mãe e ao R.N. considerados de baixo risco, permitindo identificar as possíveis complicações garantindo a transferência para centros especializados de forma rápida e satisfatória.

\section{OBJETIVO}

Avaliar o preenchimento correto, aplicação do partograma, identificar as principais distocias e suas recomendações durante a aplicação do partograma e ter um maior envolvimento da gestante na sua evolução, deixando ciente de todo o processo e condutas.

\section{METODOLOGIA}

Este estudo consiste em um relato de experiência em hospital privado Unimed de Araçatuba no período de 2017 à 2018 após aplicação da lousa de partograma.

\section{RESULTADOS}

Percebemos que em alguns casos 0 preenchimento foi incompleto dificultando a participação da gestante. Houve um envolvimento das gestantes no processo da evolução do seu trabalho de parto, onde é explicado pela enfermeira obstetra as linhas de alerta, ação e as condutas a serem tomadas quando atingir esse nível. Foi constatado a satisfação das gestantes e a compreensão nas condutas médicas nas distocias.

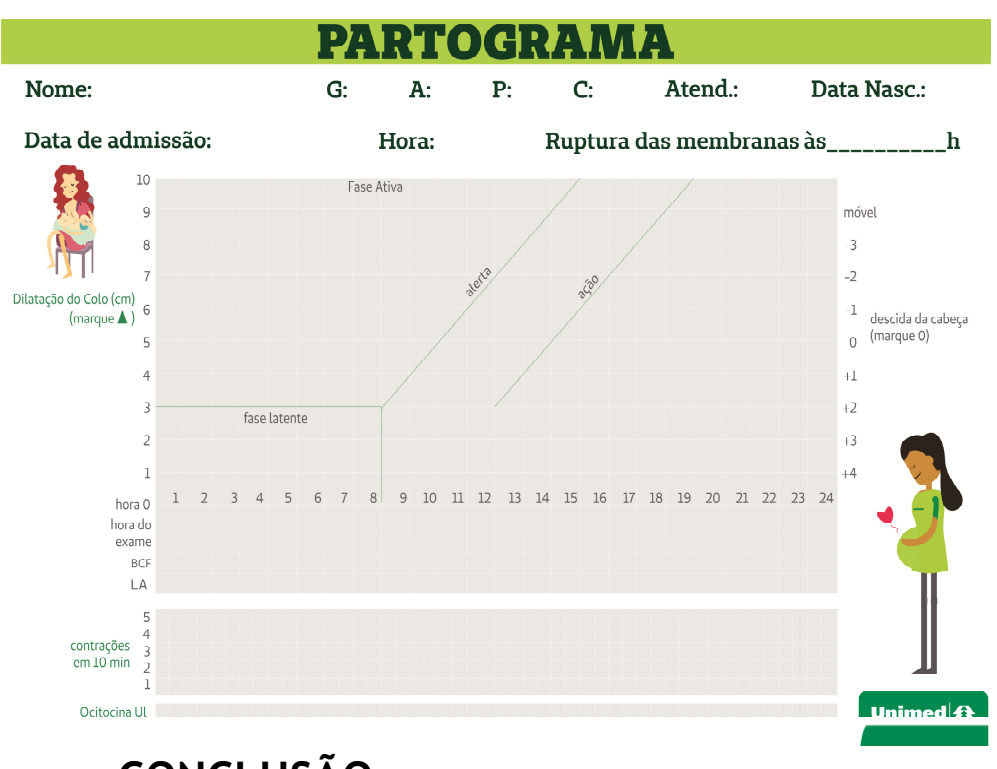

\section{CONCLUSÃO}

Quando utilizado de forma adequada, o Partograma promove uma segurança durante a assistência. É necessário garantir o preenchimento adequado de todos os itens composto no partograma para promover uma assistência obstétrica de qualidade.

REFERÊNCIA: 1. KS Rocha, CS Santos, NS Góis et al., eventos.set.edu.br Aplicabilidade e Preenchimento Correto do Partograma como Instrumento de Segurança na Assistência Obstétrica. May 9-12,2017. 2. IM Filho, D Barreto, O Santos,et al. A Eficácia da Implementação do Partograma na Assistência a Parturiente. citado 10dez.2018; http://revistasfacesa.senaaires.com.br/index.php/iniciacao-cientifica/article/view/993.MJ LIMA, AR 